\title{
KIRJALLISUUS
}

\section{Minä ja sinä - tutustu molempiin rohkeasti}

Miriam Attias \& Jonna Kangasoja (toim.)

ME JA NE Välineitä vastakkainasettelujen aikaan. Into-kustannus. 250 s. 2020.

\section{Miksi kirjaa tarvitaan?}

Sovittelun ammattilaisten Miriam Attiaksen ja Jonna Kangasojan toimittama artikkeliteos ME JA NE - välineitä vastakkainasettelujen aikaan on syntynyt yhteiskunnallisen keskustelun kärjistymisen ja lisääntyneen vihapuheen myötä. Viimeisimmän sysäyksen kirjan synnylle antoi vuoden 2015 ennennäkemättömän laaja turvapaikanhakijoiden tulo eri puolelle Suomea. Rauhanomaiselle rinnakkaiselolle ja konfliktien sovittelulle tuli tarvetta eri kulttuurien välisten yhteentörmäysten purkamisessa.

Tähän kirjaan on koottu tunnettujen sovittelun asiantuntijoiden ja tutkijoiden puheenvuoroja konfliktien ja polarisaation synnystä ja purkamisesta, rauhantyön teorioista, työkaluista ja käytännön esimerkeistä. Kirja on jaettu kolmeen osaan: Näköaloja, Työvälineitä ja Syitä optimismiin. Kirja koostuu 14 artikkelista, jotka täydentävät toisiaan. Jokainen osa alkaa tositapahtumiin perustuvalla tarinalla. Koko kirjan läpi kulkevana punaisena lankana välittyy aidon kohtaamisen ja vuorovaikutuksen merkitys konfliktien eskaloitumisessa ja purkamisessa.

\section{Näköaloja}

Miriam Attias \& Bart Brandsma painottavat identiteetin erilaisuutta konfliktien ja polarisaation syynä ja lähtökohtana. Mustavalkoinen me ja ne -ajattelu ja siitä johtuvat tulkinnat vahvistavat konfliktien syntyä. Polarisaation dynamiikan ymmärtäminen auttaa näkemään, miksi yksinkertaisesta erimielisyy- 
destä leimahtaa usein vahva vastakkainasettelu. Jos vuorovaikutusta ei ole eri kulttuurien välillä, me ja ne etääntyvät toisistaan entisestään. Polarisaatio saa polttoainetta ryhmiä määrittelevästä identiteettipuheesta, joka kehittyy usein vaivihkaa. Artikkeli haastaa lukijaa pohtimaan, miten puhun ryhmistä, eroista ja erilaisuuksista.

Artikkeli luotaa syvälle ihmismieleen ja kertoo polarisaation aikaansaamien vaistomaisten tunnereaktioiden liittyvän puolustusmekanismeihin. Puolustautuminen johtuu henkiinjäämisestä, ja siitä vastaa ihmisen aivojen vanhin osa: liskoaivot. Ihmisen DNA:han koodattu vaistomainen puolustusreaktio on taistella, paeta tai jähmettyä. Siinä tilassa ihminen ei ajattele rationaalisesti eikä näe vaihtoehtoisia toimintatapoja. Hän ei vastaanota faktoja eikä kuuntele järjen ääntä.

Säilyttääksemme yhteiskuntarauhan on tärkeää osata elää ja toimia polarisaation kanssa! Kun ollaan ratkaisemassa konflikteja ja halutaan toimia rauhaa rakentavalla ja vastakkainasettelua purkavalla tavalla, on tärkeää punnita tarkkaan sanavalintoja ja kommunikoinnin tapaa. Rauha ei tarkoita konfliktien poissaoloa vaan monia onnistuneesti ratkaistuja konflikteja.

Marie Makweri ravistelee artikkelissaan suomalaisten ajattelua kertomalla riipaisevia tarinoita Balkanin ja Ruandan sisällissotien rauhantyöstä. Hän haastaa suomalaista yhteiskuntaa rakentamaan yhteistä tilaa, jossa kaikkien väestöryhmien edustajilla on hyvä ja turvallinen olla. Muurien rakentaminen ei ole oikea vastaus turvallisen yhteiskunnan luomiseen. Sen sijaan rohkeus, toimeen tarttuminen ja kova työ ovat hyviä keinoja liikkeelle lähdössä. Sovittelevassa työotteessa on tärkeää tarjota tila, jossa asianosaiset voivat kohdata toisensa ja olla keskinäisessä vuorovaikutuksessa turvallisessa ja tasa-arvoisessa ympäristössä. Tällainen tila tarjoaa hyvät edellytykset aidolle ja rakentavalle keskustelulle, jossa uskalletaan kohdata myös ennakkoluulot, ristiriidat ja menneisyys. Me ja ne -ajattelua voidaan tietoisesti rakentaa ja voimistaa, mutta sitä voidaan myös purkaa ja vähentää tarkoituksenmukaisilla toimilla.

Panu Artemjeff esittelee omassa artikkelissaan Britannissa kehitettyä ihmisoikeusinstituutin ja yliopistojen yhteistyössä syntynyttä Hyvien suhteiden viitekehystä (GRMF), joka määritellään neljän osa-alueen avulla: Asenteet (suhtautuminen toisiin), Henkilökohtainen turvallisuus (turvallisuus julkisissa tiloissa), Vuorovaikutus toisten kanssa (vuorovaikutus eri väestöryhmien välillä) sekä Osallistuminen ja vaikuttaminen (osallistuminen yhteiskunnalliseen toimintaan ja tapahtumiin ja kokemus toimijuudesta). 
Yksilön kokemukset asenteista, turvallisuudesta, vuorovaikutuksesta sekä toimijuudesta vaikuttavat ihmisen arkeen: negatiivinen asenne ja sosiaalinen hyljeksintä heikentää syrjintää kokeviin ryhmiin kuuluvien henkilöiden mahdollisuuksia kiinnittyä ympäröiviin yhteisöihin ja yhteiskuntaan.

Jotta ihmisen itsetietoisuus ja identiteetti voi syntyä ja kehittyä vahvaksi ja hyväksytyksi, tarvitaan vastavuoroisia tunnustussuhteita toisten kanssa: kunnioitusta (turvataan lainsäädännöllä, jakamaton ihmisarvo), arvostusta (perustuu tietoihin, taitoihin ja osaamiseen - ei ihonväriin, sukupuoleen, seksuaaliseen suuntautumiseen) ja rakkautta (liittyy ainutkertaisiin yksilöihin ja tunnesuhteisiin tiettyjen ihmisten kesken).

\section{Työkaluja}

Kirjan toisessa osassa esitellään konkreettisia keinoja sovintotyöhön, jossa oikea-aikaisuus ja oikean toimenpiteen valitseminen on tärkeää. Ennaltaehkäisy nähdään edullisimpana keinona ja siksi yhteiskunnassa - ja kirkossa - on vaalittava suhteiden luomista, yhteyksien avaamista ja yhteistyön rakentamista, yhteydenpidosta sopimista, kaikille avoimia tilaisuuksia sekä matalan kynnyksen yhteydenpitoa.

Ennaltaehkäisevä dialogi luo toimivia suhteita. Tällaisia ennaltaehkäisevän dialogin keinoja ovat tutustuminen eri kulttuureihin, uskontoihin tai keittiön erityispiirteisiin. Näillä tavallisilla asioilla tavoitellaan rauhanomaista yhteiseloa, yhteisymmärrystä, harmoniaa ja uteliaisuutta erilaisuutta kohtaan!

Jakautuneiden yhteisöjen ja katkenneiden siteiden uudelleenrakentamisessa nostetaan esille ihmisen kolme perustarvetta: turvallisuus, palkitsevuus ja yhteys. Kirjan toinen toimittaja, Kangasoja, peräänkuuluttaa, että haastavien yhteisten asioiden hoitamiseen on pystyttävä luomaan sellaisia osallistumisen tiloja ja tilanteita, joissa osallistujille ei pääse syntymään kokemusta uhattuna olemisesta, vaan joissa he kokevat osallistumisen itsessään palkitsevana ja voivat siten luoda toisiinsa merkityksellisiä yhteyksiä.

Narratiivinen sovittelu lähtee siitä, että löydetään merkityksiä ihmisten tarinoille ja pyritään ymmärtämään muiden ja omia kokemuksia. Ryhmissä tapahtuvalla elämäntarinoiden jakamisella voidaan muokata omaa identiteettiä ja kuvaa siitä, kuka minä olen ja kuka sinä olet.

Tunteilla on oma merkityksensä ristiriitojen ja dialogin keskellä. Erityisen herkkänä on oltava omien häpeän, syyllisyyden ja inhon tunteiden kanssa. 
Viritessään nämä tunteet jäävät usein tiedostamattomiksi ja alkavat salakavalasti ohjata toimintaa. Kun on riittävän selvillä omasta tunnehistoriastaan, voi yrittää kuulla tarkkaan ja ymmärtää, mitä toisten ihmisten kokemukset ovat ja millaista informaatiota tilanteen nostattamat tunteet herättävät minussa. Näin oman empatian avulla tavoitetuista tunteista tulee tärkeää informaatiota, jota ammattilainen voi käyttää tilanteen ymmärtämiseksi ja osapuolia eteenpäin saattelevien kysymysten muotoilemiseksi.

\section{Syitä optimismiin}

Kirja päättyy Pasi Saukkosen artikkeliin, jossa muistutetaan maapallon kutistuminen yhdeksi keskinäisriippuvaiseksi paikaksi ja maalataan haasteita silmiemme eteen: "Monet elävät monipaikkaista ja ylirajaista elämää, jossa jäsenyyden määrittely on aikaisempaa vaikeampaa. Tämän kompleksisen moninaisuuden kanssa ei ole vielä missään kunnolla opittu elämään.”

Tämän kompleksisen moninaisuuden keskellä meillä on otettavaksi neljä askelta. Ensimmäinen askel oikean tien suuntaan otetaan ymmärtämällä se, että suvereenin kansallisvaltion sisältämä selvärajainen moderni yhteiskunta ei ole kehityksen päätepiste. Toinen askel on hyväksyä yhteiskuntien sisältämä erilaisuus ja sen jatkuva sosiaalinen uudelleen organisoituminen. Kolmas askel on muistutus siitä, että kulttuurien ja uskontojen moninaisuus on sekä rikkautta että erimielisyyttä ja konflikteja synnyttävää. Neljäs askel on ihmisten pyrkimys eroistaan ja erimielisyyksistään huolimatta kokea yhteenkuuluvuutta ja solidaarisuutta toisiaan kohtaan.

Suosittelen kirjaa kaikille, jotka haluavat oppia ymmärtämään itseään sekä omia tunteitaan ja reaktioitaan itselle vieraan ja erilaisen lähellä. Kirja antaa myös konkreettisia työkaluja eri kulttuureista ja uskonnoista tulevien ihmisten (ryhmämuotoiseen) kohtaamiseen ja monenlaiseen sovittelutyöhön.

Hanna Niemi 